\title{
Continuing Without Closure: Analysing Irresolution in the Old Norse Hildr Legend
}

\author{
Katherine Marie Olley ${ }^{1}$ (D)
}

Published online: 30 April 2018

(C) The Author(s) 2018

\begin{abstract}
The article introduces Old Norse material into the ongoing critical discussion about resistance to closure in medieval literature, a discussion traditionally dominated by Old French and Middle English texts. The failure of narrative accounts of the Old Norse Hildr legend to resolve is embodied by the tableaux of the eternal battle at the legend's climax, an impasse which nevertheless functions as a closural device and unites the retellings of the legend around the theme of battle. The open nature of the impasse, however, encouraged medieval authors to work on constructing narrative closure within their own accounts of the legend, not only by writing new endings but also new beginnings for the battle, elaborating on the motivations behind it. Such a strategy confirms that in Old Norse texts, as in wider medieval literature, concepts of closure involved more than merely the ending of a narrative but embraced its broader structure and invites further comparison with other medieval European texts. Finally, in taking as its starting point not a text but a legend, the article aims to explore how issues of openness versus closure can be usefully applied to a narrative unconfined by a single text but represented rather in a nexus of texts with little in common besides a brief overlap in subject matter. The article argues for the necessity of the legendary perspective, in spite of its methodological challenges, in order to distinguish between closure on a textual and closure on a narrative level.
\end{abstract}

Keywords Old Norse · Middle High German · Hildr legend · Closure

Katherine Marie Olley

katherineolley@googlemail.com; ko302@cam.ac.uk

1 Department of Anglo-Saxon, Norse and Celtic, University of Cambridge, Trinity College,

Cambridge CB2 1TQ, UK 


\section{Resistance to Closure in the Hildr Legend}

It has been convincingly demonstrated in recent scholarship that the medieval period abounded with texts which either struggled or deliberately experimented with ideas of closure versus irresolution. Reed (1990) has identified what he called an "aesthetics of irresolution" in Middle English debate poetry. Hult (1982) has drawn attention to the contradictory and cyclical ending of the Oxford Roland, which ends with Charlemagne being sent on a new Crusade, and has explored the possibility that the closing line may be scribal rather than authorial. Griffin (2005) has discussed the cyclical structure and multiple endings of the French (Arthurian) Vulgate Cycle, while Tether (2012) has examined the many responses to the unfinished romance, Perceval, both those which seek to provide closure and those which have no drive towards completion. Bruckner (1993) has also explored issues of closure in relation to twelfthcentury French romance more broadly. The continuation of Guillaume de Lorris's text of the Roman de la Rose by Jean de Meun and the many arguably unfinished works of Chaucer, such as the House of Fame and the Canterbury Tales, have all been explored by Rosemarie P. McGerr in Chaucer's Open Books: Resistance to Closure in Medieval Discourse (1998), perhaps the most comprehensive survey of medieval texts' ambivalent relationship with literary closure to date.

McGerr (1998, p. 43) highlights how, contrary to many modern assumptions, "[r] esistance to closure did, in fact, occur in medieval literature". Indeed, she emphasizes the similarities between the medieval and the modern approaches: "it is clear that medieval discussions of the structure and composition of literature do suggest the importance of strong literary closure, but for many of them, as for many modern theorists, closure involves a complex set of ideas about the entire structure of a text and not just what appears in the conclusion per se" (McGerr 1998, p. 26). Comprehensive as McGerr's work is, she admits that "[e]xactly how extensive medieval subversion of closure was and how clearly that subversion relates to a theoretical or historical framework certainly remain issues for further investigation" (1998, p. 43). Moreover, McGerr draws her examples principally from Middle English and Old French literature and these languages have dominated the discussion of medieval literary closure. This article aims to contribute to the ongoing debate from the hitherto neglected perspective of Old Norse literature and thereby testify further to the extent of medieval subversion of closure on which McGerr speculates. In addition, by taking as my starting point not a text but a legend, I wish to explore how issues of openness versus closure can be usefully applied to a narrative unconfined by a single text, but represented rather in a nexus of texts with no unity of purpose or form and little generically in common besides a brief overlap in subject matter.

The Old Norse Hildr legend is just such a nexus of texts and, in spite or perhaps because of the narrative's evident struggle with closure, it exerted a powerful and prolonged pull on authorial imagination in the Middle Ages. The legend tells of Hildr, ${ }^{1}$ who is abducted (whether she goes willingly or unwillingly is open to

\footnotetext{
1 The Norse versions of the names Hogni, Heðinn and Hildr will be used as standard throughout. However, in quotations and translations nominal orthography follows that of the relevant witness.
} 
debate) by the marauding king, Heðinn, and carried away by him on his ship, while her father, King Hogni, is away. Hearing of his daughter's fate, Hogni pursues the couple by sea and finally catches up with the pair on an island where, after attempts at reconciliation fail, he offers battle. Neither side is able to overcome the other, however, because every night, when the day's fighting is through, Hildr goes among the slain and raises the dead of both armies so that they can fight again the next day. Thus begins the so-called Hjaðningavíg, the eternal battle of the Hjaðnings; a powerful, visual embodiment of the legend's endless deferral of closure.

Before proceeding further, let us clarify exactly what is meant by closure in this context. Scholarship is littered with numerous forms of closure: thematic closure; narrative closure; aetiological closure; erotetic closure; tellability closure (Asper 2013; Carroll 2009; Klauk et al. 2016). When it comes to a broad definition, however, most scholarship on closure, including McGerr's, has operated in the shadow of Barbara Herrnstein Smith's influential explanation that, "the sense of closure is a function of perception of structure" (1968, p. 4), or, to put it another way:

the occurrence of the terminal event is a confirmation of expectations that have been established by the structure of the sequence, and is usually distinctly gratifying. The sense of stable conclusiveness, finality, or 'clinch' which we experience at that point is what is referred to here as closure. [...] Whether spatially or temporally perceived, a structure appears 'closed' when it is experienced as integral: coherent, complete and stable (1968, p. 2).

There is thus an inherent subjectivity to the debate, since closure is always judged and experienced by an audience and evaluations of closure will inevitably vary according to different audiences, times and places.

This variation in the evaluation of closure is especially true of medieval texts, for which we are not the intended audience; our evaluation of closure with regard to them may differ accordingly from that of the contemporary audience. Likely oral performance and transmission of texts means medieval audiences received them in circumstances vastly different to our own habits of silent reading and undoubtedly had different ideas as to what constituted a good ending or indeed a good story. Moreover, the perception of structure in a text or narrative demands the structure under evaluation be complete but the integrity of the medieval text is troubled in numerous ways: first, the text may only have survived in fragmentary form; second, the preservation, compilation and arguably composition of many medieval texts leaves the editor unsure where the boundaries of the individual text lie, uncertain of what constitutes either the beginning or the ending or both; and third, the existence of multiple versions or redactions of a text rejects the idea of an authorized single 'whole'. As Zumthor (1978) has argued, the site of totality may be located elsewhere, for example, in a nexus of texts all expressing the same narrative.

These issues are only multiplied when the narrative under discussion is not confined to a single text or even set of related texts but refracted across any number of witnesses, textual and non-textual. As much as the medieval text is a varied and unstable entity the medieval legend is more so. To ask whether such a legend achieves closure is instantly problematic because a legend is almost by definition 
indefinitely open and subject to reinterpretation and change. Like Tristan and Iseut or tales of King Arthur and the Round Table, those "magnets for the medieval imagination" identified by Bruckner in a romance context, the Hildr legend "forms a growing reservoir of tradition [the limits of which remain unbound] within which to situate individual versions as fragments" even while discussions of closure within such texts frame them not as fragments but whole entities (Bruckner 1993, p. 216). The episodic nature of the accounts of the Hildr legend within the broader narrative structures of the legend's textual witnesses only magnifies this oscillation between fragment and whole as it is repeated again on an intermediary level. The open legend is inserted within other textual wholes which are simultaneously negotiating their own attempts to evoke a sense of closure in their audience.

The medieval textual witnesses to the Old Norse Hildr legend are diverse, incorporating both oral and written discourse, poetry and prose, multiple languages, genres, authors and audiences. ${ }^{2}$ Bragi Boddason's ninth-century skaldic shield poem Ragnarsdrápa, is a complex, tightly metrical poem, supposedly composed in praise of viking chieftain Ragnarr loðbrók. ${ }^{3}$ Ragnarsdrápa is itself only preserved in Snorri Sturluson's thirteenth-century Prose Edda, in his second section, Skáldskaparmál [the language of poetry], where Snorri, an Icelandic mythographer, poet and politician, gives his own prose account of the legend. ${ }^{4}$ A brief account is included in the twelfth-century poetic metrical catalogue Háttalykill [key to metres], supposedly composed by Orkney earl Rognvaldr kali Kolsson together with the Icelandic Hallr Pórarinsson. Lengthier accounts can be found in Saxo Grammaticus' Gesta Danorum, Book 5, also from the twelfth-century and in the fourteenth-century anonymous short Icelandic prose tale Sorla páttr [The short tale of Sorli]. ${ }^{5}$ There are also numerous non-Scandinavian analogues, ${ }^{6}$ among them the thirteenth-century Middle High German epic poem Kudrun. Being Middle High German rather than Old Norse, it lies slightly outside of the scope of this analysis, but I include it here for comparative purposes. The Kudrun is noticeably distinct from the Scandinavian treatments of the legend, presenting what appears at first to be a more 'closed' narrative than the Scandinavian witnesses and comparison may thus shed light on

\footnotetext{
2 The comic ríma Skiðaríma also makes reference to the legend. Surviving only in post-medieval manuscripts, Tómasson (2000, p. 197) has suggested it was known "at least towards the end of the sixteenth century", but concedes that "[d]ating it any earlier seems problematic". O'Connor (2012, p. 485 n. 26) concurs, arguing the rima is "probably medieval, but its pre-Reformation dating is extremely uncertain". Since this is a discussion of medieval closure only, I have not gone so far as to include Skiðarima in the main analysis.

3 For an edition of the reconstructed 'complete' poem, see Clunies Ross (1973) or Olsen (2010, pp. 43135).

4 The U-text of Snorri's work, however, called the Uppsala Edda, does not include the verses from Ragnarsdrápa. See Pálsson (2012).

5 Sometimes called Heðins saga ok Högna, it will here be referred to as Sorla páttr throughout.

6 Aðalheiður Guðmundsdóttir (2012, p. 65) identifies twelve non-Scandinavian analogues: Widsith; Deor; Das Alexanderlied; Kudrun; Beowulf; Branwen verch Llýr; Marvels of the East; Immram Brain; Annot and Johon; Dukus Horant; Konig Rother; and Wartburgkrieg. Though she admits that some bear only a passing resemblance to the Scandinavian Hildr legend. The Shetland ballad Hildina, however, is lacking from her list. Kershaw (1921, pp. 217-219) includes a translation of the first twelve stanzas, but for the fullest interpretation of this difficult text, see Hægstad (1900). Krappe (1932) also discusses the Waltharius as an analogue of the Hildr legend.
} 
whether the legend's struggle with closure can be characterized as a purely Scandinavian phenomenon.

The Kudrun's more traditionally 'closed' ending may in part be due to the fact that in the Kudrun, unlike in the Scandinavian witnesses, the narrative of the Hildr legend is not embedded in a larger structural and narrative context. In Ragnarsdrápa the legend is presented as just one of many depicted on a magnificent shield, gifted to the poet by his patron, the Ragnarr of the title, and which has precipitated the composition of the shield poem in thanks. In Háttalykill the legend is afforded one double stanza out of a total of forty-one and the narrative is recounted via questions and answers. Both poetic accounts are necessarily brief and oblique in some of their references and focus on the circumstances immediately before and during the battle. Snorri includes two accounts in his Edda, the first a prose version in Skáldskaparmál, which clearly draws on Ragnarsdrápa but expands the earlier portion of the legend to include more details about the abduction and pursuit, and the other a brief verse rendering in the third section, Háttatal [list of verse-forms], which emphasizes Hildr's seductive power over Heðinn (Quinn 2007). Both accounts are only minor components in his broader work, which looked to curry favour with the king of Norway, Hákon Hákonarson, and to codify a much broader array of poetic and legendary material than the Hildr legend alone. The Gesta Danorum situates the legend within a much broader narrative about King Frothi, the over-king of both Hogni and Heðinn, and his establishment of law and order within his purview, which is upset by the actions of both his vassals. Sorla páttr surrounds the central conflict with a mythological framework in which the goddess Freyja's necklace is stolen and she is forced to stir up trouble between two evenly-matched kings to negotiate the ornament's return from Óðinn, whilst the páttr as a whole is recorded within the Saga of Óláfr Tryggvasonr to which it is linked by that king's appearance to resolve the battle at the end of the narrative. In contrast, the Kudrun represents an expanded form of the legend, fixing it within a courtly milieu and incorporating a far larger cast of characters. The epic poem relates three abductions across three generations; Hagen is abducted in his youth by a griffin and raised in the wild; his daughter Hilde is abducted by the envoys of her suitor and future husband, Hetel; and finally, Kudrun herself is abducted by her thwarted suitor, the Norman prince Hartmuot, and eventually rescued by her future husband, Herwig, king of the Hegelings. Unlike the Scandinavian witnesses, the Kudrun removes the eternal aspect of the battle, although the third abduction does precipitate a 13-year long enmity between the Hegelings and the Normans, but this is ultimately overcome by a rash of aristocratic marriages at the poem's finale.

As Rebecca S. Beal has articulated in an Italian and French context "the ending of an inset narrative [...] differs from the final closure of the overarching narrative in its temporary, provisional nature. It cannot provide an unambiguous evaluation of the narrative it finishes because it must open up the larger narrative" (Beal 2000, p. 183). Indeed, she characterizes the inset narrative as "a locus of intense textual play" where the relative openness and closure of a text is negotiated and explored (Beal 2000, p. 195). Such a phenomenon may also be observed in each of the Scandinavian texts where the larger narrative is an important consideration determining their handling of the resolution of the Hjaðningavíg. 
With the possible exception of the Kudrun, the failure of these accounts of the Hildr legend to resolve, as embodied by the final tableaux of the eternal battle, is self-evident since, although the majority of the witnesses continue the narrative on to an ending past this point, their conclusions do not offer any closure to the predicament in which Hildr, Hogni and Heðinn find themselves. ${ }^{7}$ Háttalykill refers vaguely to some far-off conclusion, declaring "peir sijd arla sættast" (Háttalykill 23a.7, p. 26), ${ }^{8}$ possibly an elliptical reference to ragnarøkr, the end of the world in Norse cosmology, when Snorri also believed the fight would end according to his declaration: "Svá er sagt í kvæðum at Hjaðningar skulu svá bíða ragnarøkrs" (Skáldskaparmál, ch. 50, v. 1, p. 72), ${ }^{9}$ though the poetry he actually quotes makes no mention of this. Saxo, meanwhile, strives for historical realism, in keeping with his general attitude as a historian in comparison to Snorri's general attitude as a mythographer (Clunies Ross 1992). He, therefore, downplays the image of the fight unresolved, relegating the reanimation of the dead to a passing acknowledgement of popular belief by concluding the episode with the offhand observation that "ferunt Hildam tanta mariti cupiditate flagrasse, ut noctu interfectorum manes redintegrandi belli gratia carminibus excitasse credatur" (Gesta Danorum 5.9.1, v. 1, p. 332). ${ }^{10}$ Finally, Sorla páttr resolves the battle in favour of a third party, Ívarr ljómi, a Christian retainer of Óláfr Tryggvasonr, who, by virtue of his faith, is able to kill permanently all of the cursed men; an ending which is to be understood as serving a larger purpose in the narrative context of the Saga of Óláfr Tryggvasonr, within which the páttr is set (Rowe 2002, p. 63).

All these conclusions have in common a refusal to make any final judgement between Hogni and Heðinn. These are endings which bring resolution only to the extent that, in the context of the dissolution of the Old Norse cosmological and divine order represented by ragnarøkr and the coming of Christianity, the Hjaðningavig ceases to be relevant; they are not solutions to the conflict itself because, beyond the end of the world as they know it, they offer no closure to the conflict. The tableaux of two armies locked in eternal combat remains the legend's lasting impression, not one of integrity, coherence, stability or completeness.

\footnotetext{
7 Ragnarsdrápa is the exception where, perhaps due to the pictorial inspiration behind the poem's account of the eternal battle, the narrative, if the poem's static description can be called as such, does not have an ending but leaves the battle entirely unresolved.

8 'They [the Hjaðnings] will be reconciled late.' Jón Helgason and Holtsmark (1941). All references to Háttalykill are to this edition (henceforward Háttalykill); all translations of Old Norse are my own. Translations of Háttalykill are informed by Quinn (2006, p. 808).

9 'So it is said in poetry that the Hjaðnings must thus wait for ragnarøkr.' Faulkes (1998). All references to Skáldskaparmál are to this edition (henceforward Skáldskaparmál); translations of Skáldskaparmál, including Ragnarsdrápa are informed by Faulkes (1987).

10 'According to popular belief Hildr yearned so ardently for her husband that she conjured up the spirits of the dead men at night so that they could renew their fighting.' Friis-Jensen and Fisher (2015). All references to the Gesta Danorum are from this edition (henceforward Gesta Danorum); all translations are taken from the same (v. 1, p. 333).
} 


\section{Expectations of Resolution}

Beyond the simple fact of the Scandinavian narratives' visible failures to resolve, however, it should not go unremarked that this vision of eternal conflict is particularly troubling for an audience because of the way it distorts established methods of conflict resolution; there are numerous opportunities to forestall or end the conflict in the attested versions of the legend but, far from providing resolution, they only aggravate the situation. First, the abduction itself confounds the traditional notion of using women to foster peace by marriage. As the ending to the Kudrun demonstrates, marriage in medieval literature was frequently depicted as a force for social cohesion. Even leaving aside the complex historical reality of marriage, the ritual evokes a sense of resolution; as Bruckner (1993, p. 214) identifies, "certain moments in human experience furnish a sense of closure", both death and marriage among them. In more explicitly anthropological terms, "the marrying off of a woman (to quote Marcel Mauss) is part of a 'prestation total'. The relation brought about by it is a total relation. A situation of conflict or war is opposed to it. In the latter kind of relation no exchange of goods and women takes place, and hostility is the all important factor" (Molenaar 1982, p. 41). The consequences of Hildr's abduction are particularly jarring, therefore, since her attempted marriage produces a diametrically opposite effect to that usually intended when a woman leaves her kin-group to join another. Instead of creating a new generation with ties to both kingroups, Heðinn risks all to marry Hildr only to be trapped in a sterile union in which the only creative forces are (mis-)directed towards those already dead. That this destruction and perverted creativity is blamed squarely on Hildr herself, as the sorceress who prevents the battle from resolving, is even more telling, inverting emphatically the idealistic notion of the woman as an agent and guarantee of peace.

Similarly, battle in Old Norse literature is a traditional method of conflict resolution. Its social function, according to Judy Quinn, was "to resolve disputes by the exercise of co-ordinated martial power" (2006, p. 809). Equally important for our understanding of the Hildr legend's eternal battle, is the fact that in the accounts of the legend battle itself is already a method of last resort, only exploited when other methods of settlement have failed. In all the Scandinavian prose versions of the legend, battle is preceded by some verbal attempt at reconciliation. The inadequacy of such attempts is clearly underlined in Saxo's Gesta Danorum; although legal judgement is passed by Hogni and Heðinn's mutual over-king, Frothi, the failure to achieve reconciliation by legal means is explicitly highlighted:

Qua cognita iuxta legis a se latę formulam pronuntiauit. Videns autem ne sic quidem eos in gratiam reduci posse patre filiam pertinacius reposcente litem ferro decidendam edixit. Id quippe solum dirimendę controuersię remedium uidebatur (Gesta Danorum 5.9.1, v. 1, p. 332). ${ }^{11}$

\footnotetext{
11 'When he [Frothi] had learnt this [the reason for their quarrel], he pronounced judgement according to the terms of the law he had passed. However, seeing that even this would not reconcile them as long as the father obstinately demanded back his daughter, he decreed that the dispute should be settled by a sword fight. It seemed the only way of bringing their strife to an end.' (Friis-Jensen and Fisher, v. 1, p. $333)$.
} 
A strong narrative expectation is built up that the battle between Hogni and Heðinn will decide Hildr's fate, but instead of forcing a settlement, battle has the opposite effect. It complicates the matter further by trapping Hogni and Heðinn in a situation wherein not only has victory become impossible, but also retreat. It thus becomes only the latest failure in a long line of attempts at resolution, social, legal and martial.

What these different attempts at resolution demonstrate is that the Hildr legend fails to resolve on multiple levels. There is more at work here than simply a desire to keep open the larger narrative into which the accounts of the legend are inset. The locus of the irresolution is not to be found in the positioning of these retellings of the legend relative to a larger textual whole but in the substance of the legend itself. While the character of these retellings as inset narratives undoubtedly contributes to their irresolution, it is the legend that determines the lack of a sense of closure in the audience and not the nature of its witnesses. The problematic nature of the Kudrun's apparent resolution only strengthens this conclusion. As previously noted, this Middle High German variant presents a more 'closed' narrative, lacking the eternal battle motif. Nevertheless, while the text emphasizes the reconciliation achieved by the eponymous heroine at the poem's finish, the risk of yet another abduction in the next generation is only avoided by refusing to confront it and by ending the narrative before such issues may arise. Yet we are given little reason to think the marriage of Kudrun's daughter will not be as troublesome as that of Kudrun herself. Far from being circumstantial, then, the sense of irresolution offered by the witnesses of the Hildr legend is common to the legend as a whole and appears to be symptomatic of some struggle with irresolution in the legend's basic structure and subject matter, which is resistant to all the usual means of settlement. The sense of irresolution is not a refusal to offer closure in the textual space allotted but an inability to do so.

\section{The Stability of Deadlock}

It can, however, be argued that the eternal nature of the battle which concludes the Hildr legend enables it to function as a closural device even with the outcome remaining permanently undecided. The impossibility of there being a victor to the conflict means the battle represents "the stability of deadlock" (Herrnstein Smith 1968 , p. 251). The narrative's inability to obtain closure is an admission that there can be no resolution between Hogni and Heðinn, which itself evokes a sense of an ending, a feeling that though the battle continues to rage, no more can be said on the subject. The eternal battle of the Hjaðnings is an impasse, a symbolic admission that the situation cannot be adequately resolved, yet one which still imparts to the audience a sense that the story is finished. Impasse offers the prospect of both openness and closure but commits to neither; the "consequences of impasse may be traced out in opposite directions to two separate finalities or to several or to none at all" (Adams 1958, p. 211). In this sense it is an open ending but the stability it offers means it also functions as a closural device. 
The discovery of impasse in a narrative may also "be cause to reflect interestingly on the qualities of vision and character which are responsible for the impasse" (Adams 1958, p. 211), in this case Hildr herself. The impasse in the Hildr legend is a function of Hildr and her characterization not just as the daughter of Hogni and the lover of Heðinn but the personification of battle in the Old Norse poetic lexicon. Hildr is, after all, also a common feminine noun in Old Norse meaning 'battle'. In this respect, the narrative's impasse borrows a kind of aetiological closure, which explains and enacts Hildr's linguistic association with warfare. This association is admittedly more evident in Ragnarsdrápa, Háttalykill and Skáldskaparmál than in the Gesta Danorum or Sorla páttr. Hildr's identity as one of Óðinn's maidens, a valkyrie who chooses the slain and serves mead to the warriors in Óðinn's hall, seems to become ameliorated over time until it is erased almost entirely in the later retellings, but it is nevertheless a key and likely an early feature of her characterization (Malone 1964, p. 44).

Quinn has examined the portrayal of Hildr as a valkyrie in detail. She notes that Snorri does not explicitly call Hildr a valkyrie in his account of the legend in Skáldskaparmál, but suggests that her power of revivification nevertheless "parallels the valkyrie's effect in escorting the battle-slain to Valholl where they will live on, in their own mode of everlasting battle" (Quinn 2007, p. 112). In Ragnarsdrápa Quinn argues that "Hildr's goal is definitively self-interested: that hildr should continue", contrasting this indifference to human suffering with the rather more alluring portrait in Háttatal "where death by gross wounding was somehow transfigured as an erotic surrendering to a female personification of battle" (Quinn 2006, pp. 809-10). By turns bloodthirsty and seductive according to the author's preference, Hildr's mythological and linguistic identification with battle brings a sense of "thematic closure" to the legend, that is closure which occurs "once the reader realizes what the narrative is about in the sense that she identifies its central theme or themes" (Klauk et al. 2016, p. 28). This "thematic closure" is in contrast to "narrative closure", which occurs when all the presiding macro-questions proposed by the plot of the narrative have been answered; it is thus more dependent on the textual specifics of each individual retelling (Klauk, Köppe and Onea 2016, p. 24). Battle is self-evidently the unifying theme of the Hildr legend, embodied in the person of Hildr, who promotes and pursues it in the earlier witnesses. Even in the later accounts, where Hildr's valkyrie nature is less overtly depicted-“in Sorla páttr's retelling [...] the potency of Hildr is thoroughly undone" (Quinn 2006, p. 812) - she remains a vital motivating factor in the conflict.

It would be reductive to view Hildr as nothing more than a pitiless incarnation of battle, however; she is also a human woman firmly enmeshed in a familial unit. Rolf Stavnem attempts to compartmentalize the two, arguing that the conformity or deviation of the Hildr-kennnings in Ragnarsdrápa to the "common woman-kenning pattern" of a base-word modified by a verb indicates to the audience whether she is to be understood as a human or a supernatural valkyrie at the relevant point in the story (Stavnem 2004, pp. 178-79). Such a distinction is hardly preserved in Ragnarsdrápa, however. Hildr's supernatural character is not something that is switched on and off at various points throughout the poem. Her aetiological and linguistic connection with battle exists alongside her emotional connection to her 
father and lover in the various texts. Like the valkyries of the Poetic Edda-Sváva, Sigrún, Sigrdrífa or Brynhildr-Hildr is both a woman and a valkyrie, torn in different directions by her conflicting loyalties. Unlike the valkyries of the Poetic $E d d a$, however, who usually bestow their supernatural favour on a lover chosen in bold defiance of their fathers' wishes (or, in Sigrdrifa's case, the wishes of her father-figure, Óðinn), Hildr is more equivocal, refusing to choose between Heðinn and her father by resurrecting the dead of both sides every night. Such equivocation is doubtless a side effect of her aetiological function, but it nevertheless conflicts with her portrayal as both a woman and a valkyrie. It is the coexistence of these two sides to Hildr's character, the symbolic and the personal, which means that, in spite of the impasse she invokes, there are still narrative consequences remaining to be teased by curious authors and audiences, questions which remain unanswered, most obviously, the question of who wins the battle.

Medieval authors certainly chose to pursue the narrative implications further. With the possible exception of Ragnarsdrápa, which is only extant in Snorri's Skáldskaparmál, a fact which should make us wary of analyzing it as a standalone narrative, the impasse does not seem to have been completely satisfactory to medieval authors, who insisted on re-ending the narrative in their own ways, seeking closure beyond the merely thematic or aetiological. An impasse "compels the reader to draw his own conclusions" (Herrnstein Smith 1968, p. 251) and the Old Norse witnesses of the Hildr legend allow us to see how Scandinavian authors literally wrote their own conclusions to the Hjaðningavig's supposedly insurmountable deadlock. The witnesses of the Hildr legend all respond to the legend in the act of retelling it. What is startling in such a diverse array of responses is not that most narratives should strive for further closure beyond the stability of deadlock, but that they should independently pursue the same strategy to do so. Just as Adams (1958) recognized, the implications and consequences of impasse can be traced out in a variety of directions. In the case of the Hildr legend, authors constructed new endings for the Hjaðningavig, as has been discussed in Sect. 1, but that is not all. Authors consistently chose to trace these implications not only forwards to new endings, but also backwards to the motivation behind the conflict.

\section{Over-Motivation of Conflict}

The Hildr legend's failure to resolve past the stability of impasse can be contrasted with excessive impetuses to begin the battle. This continual reimagining of the beginning reveals how medieval authors and poets sought to bring further closure to the legend's deadlocked conclusion. It has become a commonplace observation in discussions of closure that examining how a text begins is at least as important as examining how it ends (Kermode 1967; Hillis Miller 1978; Bruckner 1993; McGerr 1998; Hult 1984). Opening and closing are symmetrical movements; you cannot close something unless it has first been opened; as Bruckner rightly identifies, by their very opposition openness and closure are implicated in one another. The two poles of openness and closure are, she argues, "more usefully conceived as the two ends of a continuum, where one shades naturally or imperceptibly into the other. 
Closure and open-endedness, like so many other oppositions [...], are not really incompatible; they work in tandem like non-disjunctive oppositions" (Bruckner 1993, p. 214). A closer analysis of these reimagined beginnings can shed light on why the Hildr legend struggled so profoundly with achieving final closure.

The motivation behind the onset of battle is the key point of variation across the Scandinavian versions. In Ragnarsdrápa it is heavily implied that Hildr's vicious nature is to blame, described as she is by the chilling kenning "*ofperris *æða óskRán" (Skáldskaparmál, 250.1-2, v. 1, p. 72), ${ }^{12}$ an interpretation congruent with Háttalykill's assertion that "saman hilldr lidi atte" (Háttalykill 23a.8, p. 26). ${ }^{13}$ Snorri's own retelling fits within this interpretation too. He retains Hildr's magical abilities and depicts her ambiguous, arguably provocative, attempt to broker peace with her father, but he also adds the motif of a magical sword, Dáinsleif, "er manns bani skal verða hvert sinn er bert er ok aldri bilar í hoggvi ok ekki sár grœr ef par skeinisk af” (Skáldskaparmál, ch. 50, v. 1, p. 72). ${ }^{14}$ Saxo, however, exonerates Hildr from malice, instead attributing the battle to "rem falso nuntiatam" (Gesta Danorum 5.9.1, v. 1, p. 332), ${ }^{15}$ that Heðinn dishonoured Hildr before they were married, rousing her father to take action against him even though their betrothal had originally received his full consent. Finally, Sorla páttr recounts how Heðinn is enthralled by the mysterious valkyrie Gondul, who is actually the goddess Freyja in disguise. During the abduction and under her influence, Heðinn "skaut [...] pá drottningu niðr fyrir barðit" (Sorla páttr, ch. 7, v. 1, p. 377), ${ }^{16}$ killing her. This murder of Hogni's wife, Hildr's mother, seals the enmity between Hogni and Heðinn and ensures that Hogni can never accept the peace later offered to him. Thus, the ultimate impetus for battle in the páttr can be traced back to Freyja, whose object from the páttr's beginning has been to stir up trouble between two evenly matched kings as part of a bargain made with Óðinn to negotiate the return of her prized necklace, the Brísingamen.

These various motivations behind the outbreak of the battle are far from insignificant variations in plot; their at times laboured addition to the narratives demonstrates the authors' determination to impress upon the audience that the ostensible reason for the conflict in their retelling of the legend was indeed the sole reason battle broke out, preventing any reconciliation between the two sides. Snorri makes sure to preface Hogni's explanation for his refusal to accept compensation with the heavy-handed pronouncement "of síð bauðtu petta ef pú vill sættask" (Skáldskaparmál, ch. 50, v. 1, p. 72), ${ }^{17}$ unnecessarily reinforcing the tragic timing of his decision to unsheathe Dáinsleif and implying he might otherwise have been amenable to making terms. Sorla páttr, similarly, has Hogni regretting the

\footnotetext{
12 'Wish-Rán of too great drying of veins' [> 'Goddess desirous of shedding blood'].

13 'Hildr incited the hosts [to come] together.'

14 'Which has to be the slayer of a man each time it is unsheathed, and it never fails in a blow, and no wound heals if it is cut by it.'

15 'The lying tale.' (Friis-Jenssen and Fisher, v. 1, p. 333).

16 'Pushed the queen down in front of the prow.' Guðni Jónsson (1954). All references to Sorla páttr are to this edition (henceforward Sorla páttr).

17 'You have offered this too late, if you want to reach a settlement.'
} 
circumstances which make it impossible for him to do anything but fight Heðinn, detailing his reasoning at some length:

"Ek hefða gift pér Hildi ef pú hefðir hennar beðit. Nú pó ok, at pú hefðir hertekit Hildi, pá mættim vit pó sættast fyrir pat. En nú, er pú hefir gert svá mikit óverkan, at pú hefir níðzt á drottningu ok drepit hana, er engi ván á, at ek vili sættum taka" (Sorla páttr, ch. 8, v. 1, p. 379). ${ }^{18}$

This excessive narrative emphasis on fixing the exact point at which the battle became inevitable only serves to highlight narrative discomfort around the onset of the conflict. Even more striking is the unique character of each retelling; in no two versions is the explanation for the beginning of the conflict entirely the same. Háttalykill and Ragnarsdrápa present superficially similar motivations, but there is a world of difference between the incitement referred to in the former, a fairly commonplace action for women in Old Norse texts, and the image of the bloodthirsty, terrifying "fljóða fordæða" (Skáldskaparmál, 254.3-4, v. 1, p. 73), ${ }^{19}$ created by the latter. With every version, the beginning is being constantly redrawn and reworked but to the same end, that the motive behind the eternal battle should be established beyond question. The desire for closure manifests in the "overproduction of accounts of causality" (Griffin 2005, p. 140).

Griffin analyses a similar phenomenon in the Old French Vulgate Cycle which likewise struggles to achieve closure. The Cycle, she argues, closes twice: first when Galahad, the knight "qui metra a fin les aventures de la Grant Bretaigne" (Pauphilet 2003, p. 10), ${ }^{20}$ completes the Grail quest, achieving the ultimate spiritual fulfillment. Then the Cycle closes again in the following text, the Mort Artu, wherein Arthur's world crumbles but which itself "invokes images of circularity in its constant references to the Wheel of Fortune" (Griffin 2005, p. 12) and troubles the notion of closure by ending, much like the Hildr legend, with "la guerre qui jamés ne prendra fin" (Frappier 1964, pp. 114, 118, 125). ${ }^{21}$ Like the Hildr legend, the beginning of the Cycle is also reworked. The Lancelot was the first of the texts to be written, signaling one beginning, but the Cycle begins anew with the later addition of the "prequels", concerning Merlin and the early history of the Grail (Griffin 2005, p. 12). It is worth quoting Griffin's conclusion at some length:

As narratives of beginnings are produced and superimposed within the Cycle, the Cycle also strives for closure; such an overproduction of accounts of causality indicates the text's impetus to finish, to have said all that can be said about the causes of the Arthurian universe, and about the origins of the objects it privileges. It also reveals the Cycle's complementary and contradictory inability to do so (Griffin 2005, p. 140).

\footnotetext{
18 'I would have given you Hildr in marriage if you had asked for her. Even now, although you have abducted Hildr, we two might still have been able to reach a settlement over this. But now, when you have committed such a great outrage, that you have treated the queen so shamefully and killed her, there is no hope that I would want to make terms with you.'

19 'Evil creature among women.'

20 'Who shall bring the adventures of Britain to their close.' Translation from Griffin (2005, p. 12).

21 'A war which will never come to an end.' Translation from Griffin (2005, p. 12).
} 
As Griffin observes, it is the drive to complete the text which paradoxically results in the proliferation of accounts of causality. She thus highlights the symbiotic relationship between ending and beginning, also noted by Bruckner (1993), which is so key to the Vulgate Cycle's struggle to achieve closure.

The Vulgate Cycle and the Hildr legend are two very different collections of texts and so the parallel is by no means exact but in the proliferation of motivation and impetuses for the Hjaðningavíg we see a similar tension at work. As in the Vulgate Cycle, these "narratives of beginning", to borrow Griffin's phrase, are symptomatic of a desire to close and complete the Hildr legend, something that can only be achieved by writing the end into the beginning, by going backwards to alter the initial circumstances of the conflict.

Even the Kudrun can be seen to adopt a similar approach, but rather than simply altering the immediate onset of the battle, the author instead multiplies the abduction motif across three generations, exploring it differently each time, with perpetrators both human and bestial, victims both male and female and outcomes both successful and tragic. The same anxiety to close the legend that haunts the Scandinavian texts is present in the Middle High German one, as the author writes narratives of beginning so expansive that they have become full narratives in themselves. He thus builds a pattern which both troubles attempts at closure by its cyclical nature and yet also aims for completeness, as symbolized by the four dynastic marriages at the finale, which hope to bind all the kingdoms together against the possibility of future conflict.

Elaborating on those initial circumstances which resulted in the eternal battle allowed the authors to transform the irresolution of the eternal battle into resolution on a smaller scale. The Kudrun is allowed to explore various outcomes to abduction, each time resolving the crisis temporarily, though the spectre of the next generation and, by extension, the next abduction remains an unacknowledged threat. In Háttalykill and Ragnarsdrápa, where Hildr is herself the main cause, the everlasting battle becomes the definitive triumph of Hildr's destructive powers, turning it from an impotent means to an impossible end into that end itself. Similarly, in Sorla páttr the battle achieves Freyja's object of stirring up strife between two evenly-matched kings and her necklace is, presumably, returned. In Skáldskaparmál, the drawing of Dáinsleif has its inevitable bloody consequence and the logic of cause and effect transforms the battle from an open question as to who shall triumph into the answer to the text's introduction of the sword's fateful potency. Finally, in Saxo's Gesta Danorum, where the kings mutually destroy each other, both the happy prologue of the blissful engagement and the fact that the allegations which sparked the conflict were unfounded turn the ending into a bloody dénouement reminiscent of a Shakespearian tragedy. The episode becomes a warning about the consequences of listening to false reports and denying the promptings of both vassalage and friendship.

Such a reading explains why the motivation behind the battle has sometimes seemed forced to critics. Alexander Haggerty Krappe made an important point when he noted that "the motivation of their [Hogni and Heðinn's] quarrel is nowhere really convincing and the sources do not agree" (1927, p. 142). The logical inference from the unconvincing nature of these motivations is that they are, to an 
extent, narrative devices, introduced to make the endings which follow feel more satisfactory by emphasising the logic of cause and effect. They attempt to disguise the underlying motivation behind the conflict and its impasse, namely the abduction and attempted marriage of Hildr.

Stripping away all the additional motivations, from Hildr's vengeful valkyrie nature to the murder of her mother, the fact of Hildr's abduction alone remains constant. This direct assault on Hogni's family challenges his authority as well as the safety and stability of his kingdom and must be answered. The problem is compounded by the fact that, in all the Scandinavian versions, Hildr is her father's only child; in the Kudrun, Kudrun has a brother Ortwin, yet another reason why the conflict is ameliorated in the Middle High German text. It is the apparent necessity of adding further motivation and thus moving the locus of irresolution onto different ground that suggests unease surrounding the complex realities of female exchange, as the legend both reinforces and yet attempts to deny the idea that such exchange can result in as well as resolve conflict. ${ }^{22}$ Attempts to construct an ending for the legend beyond the impasse reveal an impetus towards the narrative closure denied by the circumstances of Hildr's abduction. If the additional motivations are accepted at face value then a fragile narrative resolution can be reached. Yet these varied attempts to construct narrative closure within each individual text coexist uneasily with the thematic closure which unified the legend around the theme of endless conflict. Their separate strivings for closure, paradoxically, highlight the resistance to closure within the legend as a whole, as expressed across the entire nexus of texts.

\section{Continuing Without Closure}

An examination of the Hildr legend demonstrates beyond a doubt that Norse texts are easily as relevant to a discussion of medieval resistance to closure as texts produced in France and England and deserve further study in this regard. Like many of their continental contemporaries, these texts struggle with and yet strive for closure in their narrative accounts of Hildr's abduction and the subsequent battle. Also in common with many of their continental contemporaries, this struggle for closure involved not just the ends of these texts, but their beginnings as well. Even the Kudrun, which strives so hard to tie up all loose narrative ends, has been shown to partake of the same over-production of narratives of beginning, suggesting further study of resistance to closure in the analogues of the Old Norse Hildr legend might be illuminating. That is not to imply that these authors consciously pursued the same strategy, but it does suggest that Scandinavian authors and audiences shared the medieval conception of closure identified by McGerr (1998, p. 26) by which "closure involves a complex set of ideas about the entire structure of a text and not just what appears in the conclusion per se". Such a recognition may prepare the way for more inclusive analyses of medieval closure in future scholarship and closer

\footnotetext{
22 Intriguingly, the rape and marriage of Dinah in Genesis 34, another narrative grappling with the implications of female exchange, also results in a narrative impasse (Zeelander 2012, pp. 187-93), tentatively suggesting that the question of a daughter's divided loyalties on the occasion of her marriage may have been an unresolvable cultural problem not localized to a single time and place.
} 
comparison between closure and resistance to closure in Old Norse literature and closure and resistance to closure in contemporary European literature.

I hope also to have shown by the foregoing analysis of each individual witness's attempt to evoke closure within their retelling of the Hildr legend that not only is it possible to talk about closure with reference to an entire legend, but that it is sometimes necessary to do so. No matter how problematic it may be, given the inherent openness of a legend and its shifting definition, including different texts at different times, the concept of the legend allows for differentiation between the irresolution or closure within each text individually and that which is common to the legend as a whole. By studying at the textual and legendary level simultaneously we can begin to construct a perspective on the changing attitudes towards closure. Can it be coincidence that there is a definite shift away from openness towards closure in the younger of the Hildr legend's textual witnesses, from the more open-ended accounts in Ragnarsdrápa, Skáldskaparmál and Háttalykill to the more closed endings in Sorla páttr, the Gesta Danorum and the Kudrun, which does away with the motif of the eternal battle altogether?

The difficulty is that the very openness of the legend is what encourages our perception of irresolution in the texts that constitute it. The knowledge granted to a modern audience that there are other endings and versions of the legend out there makes such endings seem more open, less rigidly certain than they would appear, were we not aware of the legendary hinterland behind each separate retelling. It is impossible to know exactly how a medieval audience received a text but both temporal and geographical factors make it impossible that a medieval audience should have had the same conception of the Hildr legend and the same knowledge of the witnesses to it as we do today. It is only possible with hindsight to bring this constellation of texts together and in so doing discover the shifting locus of irresolution in the multiplication of motivations for the battle over time, which hints at a legendary narrative that has never and perhaps could never be closed to either a medieval or a modern audience's satisfaction.

There is evidently much to be gained from a closer analysis of the dialectic between openness and closure in Old Norse literature and legend, for both our understanding of the texts and of their place within the wider context of resistance to closure in medieval literature. Moreover, I hope to have demonstrated that the inherent openness of legend is more than just an obstacle to be surmounted when it comes to discussing closure in legendary texts and witnesses. It has long been recognized that modern notions of fixed textuality, promoted by critical editions of texts, diminish the variety and variability in medieval literature which ought to be celebrated. One response has been to promote close manuscript study, the production of diplomatic or scribal editions which encourage a step forward, towards the text, to see more by looking more closely. Alternatively, modern theory has been offered as "a means of facing up to the conceptual challenges that manuscript culture presents us with", a lens though which to read the text anew (Sunderland 2010, p. 178). Embracing the legend proves that a step back can sometimes be an equally effective remedy, revealing a broader horizon, a richer tapestry of allusion, which can only deepen our understanding of the texts to be studied. 
Acknowledgements The initial research for this paper was supported by a Newnham College Newton MPhil award (2014-2015) as part of the Cambridge Home and EU Scholarship Scheme. I am grateful for the AHRC-Trinity studentship (2015-2018) from the Arts and Humanities Research Council Doctoral Training Partnership (AHRC DTP) together with Trinity College, Cambridge [grant number AH/ L503897/1] which allowed me the opportunity to pursue this work for publication. I would also like to thank my supervisor, Dr. Judy Quinn, for her guidance and support and Dr. Miranda Griffin for her helpful comments on an earlier draft of this paper.

Open Access This article is distributed under the terms of the Creative Commons Attribution 4.0 International License (http://creativecommons.org/licenses/by/4.0/), which permits unrestricted use, distribution, and reproduction in any medium, provided you give appropriate credit to the original author (s) and the source, provide a link to the Creative Commons license, and indicate if changes were made.

\section{References}

Adams, R. M. (1958). Strains of discord: Studies in literary openness. Ithaca: Cornell University Press. Aðalheiður Guðmundsdóttir. (2012). Saga-motifs on Gotland picture stones: The case of Hildr Högnadóttir. In M. H. Karnell (Ed.), Gotland's picture stones: Bearers of an enigmatic legacy (pp. 59-61). Gotländskt Arkiv 84. Visby: Gotland Museum.

Asper, M. (2013). Minding the gap: Aetiology and (false) closure. In F. F. Grewing, B. Acosta-Hughes, \& A. Kirichenko (Eds.), The door ajar: False closure in Greek and Roman literature and art (pp. 6382). Heidelberg: Universitätsverlag Winter.

Beal, R. S. (2000). Ending in the middle: Closure, openness and significance in embedded medieval narratives. Annali d'Italianistica, 18, 179-189.

Bruckner, M. T. (1993). Shaping romance: Interpretation, truth, and closure in twelfth-century French fictions. Philadelphia: University of Pennsylvania Press.

Carroll, N. (2009). Narrative closure. In P. Livingston \& C. Plantinga (Eds.), The Routledge companion to philosophy and film (pp. 207-216). London: Routledge.

Clunies Ross, M. (1973). An edition of the Ragnarsdrápa of Bragi Boddason. Ph.D. dissertation, Unpublished. University of Oxford.

Clunies Ross, M. (1992). Mythic narrative in Saxo Grammaticus and Snorri Sturluson. In C. Santini (Ed.), Saxo Grammaticus tra storiografia e letteratura (pp. 47-59). Rome: Il Calamo.

Faulkes, A. (Ed.). (1998). Snorri Sturluson. Skáldskaparmál. 2 vols. London: Viking Society for Northern Research.

Faulkes, A. (Trans.). (1987). Snorri Sturluson. Edda. London: Dent.

Frappier, J. (Ed.). (1964). La mort le roi Artu. Geneva: Droz.

Friis-Jensen, K. (Ed.) \& Fisher, P. (Trans.). (2015). Saxo Grammaticus. Gesta Danorum: The history of the Danes. 2 vols. Oxford: Oxford University Press.

Griffin, M. (2005). The object and the cause in the Vulgate cycle. London: Modern Humanities Research Association and Maney Publishing.

Hægstad, M. (1900). Hildinakvadet, med utgreidung um det norske maal paa Shetland i eldre tid. Skrifter udgivne af Videnskabsselskabet i Christiana: Historisk-Filosofisk Klasse II. Christiana: I kommission hos J. Dybwad.

Helgason, Jón, \& Holtsmark, A. (Eds.). (1941). Háttalykill enn forni. Copenhagen: Ejnar Munksgaard.

Herrnstein Smith, B. (1968). Poetic closure: A study of how poems end. Chicago: University of Chicago Press.

Hillis Miller, J. (1978). The problematic of ending in narrative. Nineteenth-Century Fiction, 33(1), 3-7.

Hult, D. (1982). 'Ci falt la geste': Scribal closure in the Oxford Roland. Modern Language Notes, 97(4), 890-905.

Hult, D. (1984). Editor's preface. Yale French Studies, 67, iii-vi.

Jónsson, Guðni (Ed.). (1954). Fornaldar sögur Norðurlanda. 4 vols. Reykjavík: Íslendingasagnaútgáfan.

Kermode, F. (1967). The sense of an ending: Studies in the theory of fiction. Oxford: Oxford University Press.

Kershaw, N. (1921). Stories and ballads of the far past. Cambridge: Cambridge University Press. 
Klauk, T., Köppe, T., \& Onea, E. (2016). More on narrative closure. Journal of Literary Semantics, 45(1), $21-48$.

Krappe, A. H. (1927). Balor with the evil eye: Studies in Celtic and French literature. New York: Columbia University Press.

Krappe, A. H. (1932). The legend of Walther and Hildegund. The Journal of English and Germanic Philology, 22(1), 75-88.

Malone, K. (1964). An Anglo-Latin version of the Hjaðningavíg. Speculum, 39(1), 35-44.

McGerr, R. P. (1998). Chaucer's open books: Resistance to closure in medieval discourse. Gainesville: University Press of Florida.

Molenaar, H. A. (1982). Concentric dualism as transition between a lineal and cyclic representation of life and death in Scandinavian mythology. Anthropologica, 24, 29-53.

O'Connor, R. (2012). Astronomy and dream visions in late medieval Iceland: Stjörnu-Odda draumr and the emergence of Norse legendary fiction. Journal of English and Germanic Philology, 111(4), 474512.

Olsen, C. G. (2010). Ekphrasis and the Old Norse shield poem. Ph.D. dissertation, Unpublished. University of California, Berkeley.

Pálsson, Heimir (Ed.). (2012). Snorri Sturluson. Uppsala Edda. London: Viking Society for Northern Research.

Pauphilet, A. (Ed.). (2003). La queste del saint graal. Paris: Champion.

Quinn, J. (2006). The end of a fantasy: Sorla páttr and the rewriting of the revivification myth. In J. McKinnell, D. Ashurst, \& D. Kick (Eds.), The fantastic in Old Norse/Icelandic literature: Sagas and the British Isles (pp. 808-816). Durham: The Centre for Medieval and Renaissance Studies, Durham University.

Quinn, J. (2007). 'Hildr prepares a bed for most helmet-damagers': Snorri's treatment of a traditional poetic motif in his Edda. In P. Hermann, J. P. Schjødt, \& R. T. Kristensen (Eds.), Reflections on Old Norse myths (pp. 95-118). Turnhout: Brepols.

Reed, T. L., Jr. (1990). Middle English debate poetry and the aesthetics of irresolution. Columbia: University of Missouri Press.

Rowe, E. A. (2002). Sorla páttr: The literary adaptation of myth and legend. Saga-Book, 26, 38-66.

Stavnem, R. (2004). The kennings in Ragnarsdrápa. Mediaeval Scandinavia, 14, 161-184.

Sunderland, L. (2010). Old French narrative cycles: Heroism between ethics and morality. Cambridge: D. S. Brewer.

Tether, L. (2012). The continuations of Chrétien's Perceval: Content and construction, extension and ending. Cambridge: D. S. Brewer.

Tómasson, Sverrir. (2000). 'Strákligr líz mér Skíði': Skíðaríma as Icelandic carnival play? In S. Hansson \& M. Malm (Eds.), Gudar på jorden: Festskrift till Lars Lönnroth (pp. 195-212). Stockholm: Brutus Östlings Bokförlag Sympsion.

Zeelander, S. (2012). Closure in biblical narrative. Leiden: Brill.

Zumthor, P. (1978). Le texte-fragment. Langue Française, 40(1), 75-82. 